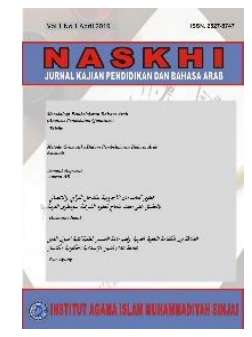

\title{
NASKHI
}

Jurnal Kajian Pendidikan dan Bahasa Arab

Volume 3, No. 1, 2021

ISSN (print) : 2527-5747

ISSN (online) : 2716-3369

Homepage : https://journal.iaimsinjai.ac.id/index.php/naskhi

\section{KAJIAN LAFAL DARI SEGI LUAS DAN SEMPITNYA MAKNA (Lafal 'Ām, Khās, Amr, dan Nahiy)}

\author{
Sardiyanah $^{1}$, Andi Muh Taqiyuddin $\mathbf{B N}^{2}$ \\ ${ }^{1}$ Institut Agama Islam Muhammadiyah, Sinjai \\ ${ }^{2}$ Universitas Islam Negeri Alauddin, Makassar \\ E-mail:sardiyanah@gmail.com,Tlp:+6285397917249
}

\begin{abstract}
The purpose of this research is to describe, to describe how the pronunciations of Am, Khās, Amr, and Nahiy, and to explain the implementation of the pronunciation of' $\bar{A} m, \mathrm{Kh} \bar{a} s, \mathrm{Amr}$, and Nahiy. This research is qualitative, the research type is library research and uses linguistic and normative approaches. The data collection method used was a literature study. The results showed that; 1) Pronounce al-Äm, before being takhsis, some say that he is hujjah zanniyah and hujjah qat'iyyah. Then the pronunciation of khas is hujjah, because the scholars agree that the pronunciation of khas is qat'i. As for the pronunciation of Amr and Nahiy are part of the pronunciation of khās, then from here, it can also be understood that the pronunciation of Amr and Nahiy can be used as hujjah, because the pronunciation of khāș is qat'iy. 2) Implementation of the Pronunciations' Am, Khās, Amr, and Nahiy respectively not only covering the origin but the breadth of their scope.
\end{abstract}

Keywords: 'Ām, Khāṣ, Amr, and Nahiy

\begin{abstract}
Abstrak
Tujuan penelitian ini untuk mendeskripsikan, memaparkan tentang bagaimana kehujjahan lafal 'Ām, Khāṣ, Amr, dan Nahiy, dan untuk menjelaskan Implementasi lafal 'Ām, Khāṣ, Amr, dan Nahiy. Penelitian ini merupakan penelitian kualitatif, jenis penelitian adalah library research dan menggunakan metode pendekatan linguistik dan normatif. Metode pengumpulan data yang digunakan adalah studi literatur. Hasil penelitian menunjukan bahwa; 1) Lafal al-'Ām sebelum ditakhșiș, ada yang mengatakan bahwa dia adalah hujjah zanniyah dan hujjah qaț'iyyah. Kemudian lafal khāṣ adalah hujjah, karena para ulama sepakat bahwa dilālah-nya lafal khāṣ adalah qaț'i. Adapun lafal Amr dan Nahiy adalah bagian dari lafal khās, kemudian dari sinilah dapat dipahami juga bahwa lafal Amr dan Nahiy dapat dijadikan sebagai hujah, karena dilālah-nya lafal khās adalah qat'iy. 2) Implementasi Lafal 'Ām, Khās, Amr, dan Nahiy masing-masing tidak hanya mencakup pada asalnya, namun luas cakupannya.
\end{abstract}

Kata Kunci: 'Ām, Khāṣ, Amr, dan Nahiy 


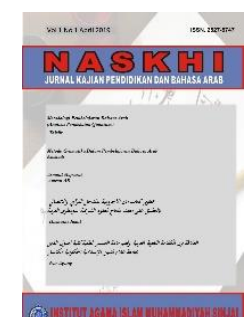

NASKHI

Jurnal Kajian Pendidikan dan Bahasa Arab

Volume 3, No. 1, 2021

ISSN (print) : 2527-5747

ISSN (online) : 2716-3369

Homepage : https://journal.iaimsinjai.ac.id/index.php/naskhi

\section{Pendahuluan}

Islam sebagai agama dan sebagai hukum, kerap gagal dipahami bukan hanya oleh orang-orang non muslim, tetapi oleh pemeluknya sendiri. Realita inilah yang sampai saat ini dijumpai dan tentunya di negeri tercinta ini sendiri. Diantara penyebab utamanya adalah keliru memahami ruang lingkup ajaran Islam, keliru menggambarkan kerangka dasar ajaran Islam, dan keliru mempergunakan metode mempelajari Islam (Ali, 2015)

Sangat logis memang jika sering terjadi blunder dalam pemahaman Islam. Karena pada zaman ketika Rasulullah masih hidup dan telah wafat tentu sangat berbeda, Nabi sebagai penentu keputusan yang ma'sum.Sehingga memang dibutuhkan konsep atau potret bagaimana memahami dan berinteraksi terhadap Islam sepeninggal nabi, termasuk hukum Islam itu sendiri. Karena bagaimanapun hukum Islam adalah bagian dari ruang lingkup ajaran Islam, bahwa kekeliruan dalam memahaminya akan berujung pada blunder pemikiran yang fatal. Diantara hasil dari blunder pemikiran hukum Islam itu adalah lahirnya paham-paham yang malah merusak citra Islam itu sendiri. Misalnya paham Islam radikal, Islam liberal, dan lain sebagainya. Maka tidak mengherankan jika Islam secara umum dan Indonesia khususnya, digemparkan oleh berbagai kasus dan isu negatif yang

menyeret nama Islam. Misalnya saja, beberapa waktu yang lalu, publik Islam umumya dan Indonesia secara khusus digemparkan dengan pernyataan Menteri Agama RI terkait Islam radikal lahir dari seorang yang good looking seperti imam, hafizh Qur'an, dan lain sebagainya (Ali, 2020). Insiden tersebut hanya salah satu diantara kejadian yang lainnya terkait Islam radikal, dan lain sebagainya. Hadirnya stigma-stigma negatif terhadap Islam tentu menjadi tamparan keras bagi umat Islam di dunia secara umum dan Indonesia secara khusus. Bagaimana tidak, dalam Islam sendiri tidak ada representasi menuju hal-hal yang berbau negatif seperti paham radikal itu sendiri. Maka salah satu langkah tepat agar tidak keliru mempergunakan metode mempelajari Islam, yaitu bahwa hukum Islam dikaji dan dipelajari dengan mempergunakan metodologi hukum Islam sendiri yang disebut usul fikih (Ali, 2015). Pada bahasan ushul fiqh, bahasa Arab adalah salah satu ilmu pendukung yang sangat penting dalam rangka menggali dan memahami hukum syara' yang bersumber dari al-Quran dan Sunnah Rasul. Hal ini sangatlah logis, mengingat nash-nash hukum Islam adalah nash-nash yang berbahasa Arab. Olehnya itu, diharuskan menguasai bahasa Arab bagi seseorang yang akan memahami nash dan menggali hukum yang terkandung di dalamnya (Sahib, 2016).

Al-Qur'an sebagai sumber hukum pertama maupun Sunnah Nabi SAW sebagai sumber kedua yang memuat nash yang menjadi dalil hukum Islam, kedua sumber hukum tersebut berbahasa Arab. Tentu untuk memahaminya dengan baik membutuhkan kemampuan memahami bahasa dan ilmu bahasa Arab yang baik pula.

Seseorang harus betul-betul mengetahui bahasa Arab dengan seluk beluknya apabila ingin mengistinbatkan atau mengambil hukum dari sumber-sumber tersebut. Kehalusan dan kedalaman yang dimaksud oleh bahasa itu (dalalahnya) harus betul-betul dimengerti. Begitu pula tentang cara mengutarakan sesuatu, harus dipahami, apakah dengan bentuk hakikat ataukah dengan bentuk majas (kiasan). Kesemuanya ini mengharuskan adanya kemampuan dalam memahami nash atau dalil dengan baik, yang kemudian hukum-hukum yang terkandung di dalamnya dapat diambil. Olehnya itu, nash atau dalil yang berbahasa Arab itu mendapat perhatian yang besar sekali oleh ulama ushul agar dapat dipahami dengan baik dan sempurna. Supaya hukum-hukum dapat dipetik dari dalil yang menjadi pegangan hukum tersebut, olehnya itu mereka telah menciptakan beberapa qaidah lughawiyah untuk dapat memahami nash atau dalil (Misbahuddin, 2015).

Maka makalah ini disusun untuk menghadirkan pembahasan mengenai beberapa bagian dari Qawa'id al-Lugawiyyah, yaitu Lafal 'Am, Khas, Amr dan Nahyun. Pembahasan pada makalah ini lebih spesifiknya yaitu, Kajian Lafal dari Segi Luas dan Sempitnya Makna (Lafal 'Ām, Khāss, Amr, dan Nahiy). Semoga pembahasan beberapa bagian dari Qawa'id al-Lugawiyyah dalam makalah ini, setidaknya bisa membantu masyarakat umumnya dan kaum muslimin khususnya untuk memahami beberapa bagian dari Qawa'id al-Lugawiyyah yaitu lafal 'Am, Khas, Amr dan Nahyun. 


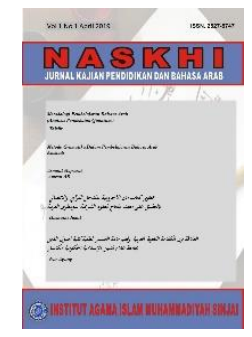

\section{NASKHI}

\section{Jurnal Kajian Pendidikan dan Bahasa Arab \\ Volume 3, No. 1, 2021}

ISSN (print) : 2527-5747

ISSN (online) : 2716-3369

Homepage : https://journal.iaimsinjai.ac.id/index.php/naskhi

\section{Metode}

Penelitian ini merupakan penelitian kualitatif, jenis penelitian adalah library research dan menggunakan metode pendekatan linguistik dan normatif. Metode pengumpulan data yang digunakan adalah studi literatur. Teknik pengolahan data pada penelitian ini yaitu, melalui editing, classifying, analysing, dan concluding.

\section{Hasil dan Pembahasan}

A. Kehujjahan Lafal 'Ām, Khās, Amr, dan Nahiy

1. Lafal ' $\bar{A} m$

'Am menurut bahasa „Aam secara bahasa adalah umum (Munawwir, 1997). Sedangkan menurut istilah ialah lafal yang menunjukkan pada jumlah yang banyak dan satuan yang termasuk dalam definisinya dalam satu makna yang berlaku. Adapun yang dimaksud dengan satu makna yang berlaku yaitu lafal yang tidak memuat arti lain yang bisa menggantikan makna tersebut (bukan musytarak). Bahwa lafal 'Ám tersebut menunjukkan arti banyak dengan memakai satu ungkapan dan dalam keadaan yang sama. Ini terdapat sedikit perbedaan dengan istilah golongan Hanafiyah. Menurutnya, lafal ' $\bar{A} m$ ialah suatu lafal yang mencakup arti secara menyeluruh, baik dengan menggunakan lafal seperti rijāl atau dengan menggunakan ism mauṣūl yang menunjukkan arti jamak atau ism syarth dan yang semisal dengannya seperti lafal qaūm, jin dan ins (Zahra, 1999). Kedua pengertian yang dikemukakan di atas, golongan Hanafiyah mendefiniskan ' $\bar{A} m$ secara rinci dengan mengemukakan beberapa unsur lafal seperti adanya ism maușūl dan isim syarț. Sedangkan pengertian lainnya lebih bersifat umum, yaitu menfokuskan pada sisi jumlah satuan lafalnya (Sahib, 2016).

'Am ialah suatu lafal yang dipakai untuk menunjukan suatu makna yang pantas (boleh) dimasukan pada makna itu dengan mengucapkan sekali ucapan saja. Seperti kita katakan "arrijāl", maka lafal ini mencakup semua laki-laki (Bakry,2003).

Lafal ' $A m$ ialah suatu lafal yang menunjukkan satu makna yang memuat seluruh satuan yang tidak terbatas dalam jumlah tertentu (Syafe'i, 2007). Dalam mendefinisikan lafal 'Ám, terdapat perbedaan di kalangan ahli ushul. Jika diteliti, dalam perbedaan itu tampak ada titik kesamaan, dan perbedaannya hanya dalam rumusannya saja karena berbeda dalam sudut pandangan.

Ibnu Subki merumuskan definisi: "Lafal yang meliputi pengertian yang patut baginya tanpa pembatasan." Abu Hasan al-Bashri yang diikuti beberapa ulama Syafii memberikan definisi, mirip dengan yang di atas: "Lafal yang meliputi semua pengertian yang patut baginya" Al-Sarkhisi (dari kalangan ulama Hanafi) merumuskan definisi: "Setiap lafal yang mengoordinasikan sekelompok nama dalam bentuk lafaz atau makna."

Dari beberapa definisi tersebut terlihat rumusan yang berbeda. Masing-masing mengandung titik lemah yang menjadi sasaran kritik pihak lain. Namun dari beberapa rumusan itu dapat ditarik hakikat dari lafaz 'am yang mencakup jiwa dari setiap rumusan, yaitu:

a. Lafal itu hanya terdiri dari satu pengertian secara tunggal

b. Lafal tunggal itu mengandung beberapa afrad (satuan pengertian)

c. Lafal yang tunggal itu dapat digunakan untuk setiap satuan pengertiannya secara sama dalam penggunaannya.

d. Bila hukum berlaku untuk satu lafal, maka hukum itu berlaku pula untuk setiap afrad (satuan definisi) yang tercakup di dalam lafal itu (Pulungan, 2020).

Lafal ' $\mathrm{Am}$ menurut ulama Hanafiyyah adalah setiap lafal yang memuat banyak baik dari segi lafal maupun makna. Menurut Syafi'iyyah suatu lafal yang dari satu segi menunjukkan dua makna atau lebih. Sementara Uddah (dari Hanbali) membuat rumusan suatu lafal yang mencakup dua hal atau lebih (Pulungan, 2020).

Muḥammad al-Khuḍarī Bik memberikan definisi 'Am sebagai berikut.

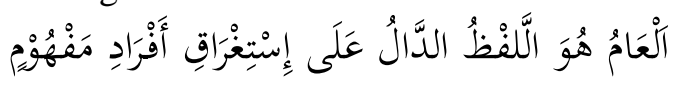




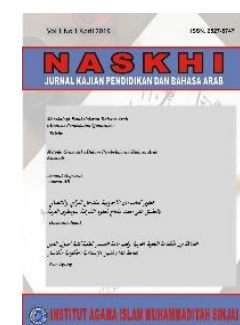

\section{NASKHI}

\section{Jurnal Kajian Pendidikan dan Bahasa Arab}

Volume 3, No. 1, 2021

ISSN (print) : 2527-5747

ISSN (online) : 2716-3369

Homepage : https://journal.iaimsinjai.ac.id/index.php/naskhi

Maksudnya:

al- 'Am adalah lafal yang menunjukan kepada pengertian dimana didalamnya tercakup sejumlah objek atau satuan yang banyak (Al-Khuḍarī Bik, 1969).

Adapun menurut 'Abdul Wahhāb Khallāf definisi 'Am sebagai berikut.

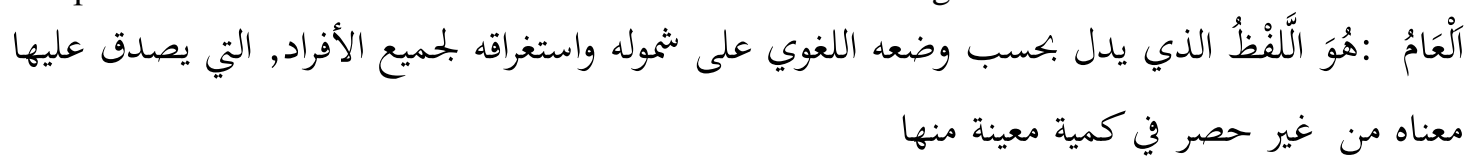

Maksudnya:

$a l$ - 'Am ialah lafal yang menurut arti bahasanya menunjukkan atas mencakup dan menghabiskan semua satu-satuan yang ada di dalam lafal itu tanpa menghitung ukuran tertentu dari satuansatuan itu (Khallāf, t.th)

Lafal 'am (umum) ialah lafal yang diciptakan untuk pengertian umum sesuai dengan pengertian lafal itu sendiri tanpa dibatasi dengan jumlah tertentu. Hakikat dari lafal 'am adalah pertama, lafal itu hanya terdiri dari satu pengertian secara tunggal. Kedua, lafal tunggal itu memuat beberapa afrad (satuan pengertian). Ketiga, lafal yang tunggal itu dapat digunakan untuk setiap satuan pengertiannya secara sama dalam penggunaannya. Keempat, bila hukum berlaku untuk satu lafal, maka hukum itu berlaku pula untuk setiap afrad (satuan pengertian) yang tercakup di dalam lafal itu (Nurhayati dan Ali Imran Sinaga, 2019).

Lafal-lafal yang digunakan untuk memberi faedah 'am antara lain: (1) Lafal kullun dan jamî'un. (2) Lafal jama' yang di-ta'rif-kan dengan idhafat atau dengan alif-lam jinsiyah. (3) Isim mufrad yang di-ta'rif-kan dengan alif-lam jinsiyah. (4) Isim-isim maushul, seperti al-ladzi, al-ladzina, al-lati, alla'i, maa dan lain sebagainya. (5) Isim-isim isyarat, seperti man, ma, dan ayyuma. (6) Isim-isim istifham (untuk bertanya), seperti man (siapakah), ma dza (apakah), dan mata (kapan). (7) Isim nakirah dalam susunan kalimat nafi (negatif) (Rosidin, 2020).

Pembahasan paling penting pada lafal $\bar{A} m$ selain pada uraian mengenai makna dan jenisnya, yaitu kehujjahan lafal tersebut. Mengenai hal ini, perlu dipahami terlebih dahulu bahwa pendapat jumhur ulama yang mengatakan tidak dapat langsung mengamalkan lafal $\bar{A} m$ tetapi harus mencari dalil yang men-takhis-kannya. Namun dalam golongan ini didapati pula perbedaan tentang batas-batas pencarian dalil yang men-takhis-kannya sebelum beramal dengan lafal $\bar{A} m$ itu. Pendapat yang mengatakan bahwa wajib mengamalkan lafal $\bar{A} m$ setelah mengetahui adanya lafal tersebut tanpa menunggu adanya penjelasan yang men-takhis-kannya (Syarifuddin, 2014) .

Disebutkan dalam kitab Ușūl Fiqh yaitu:

$$
\text { نقل كثير من الأصوليين الإجماع على جواز العمل بالعام قبل البحث عن المخصص : }
$$

Maksudnya:

Dinukilkan dari kebanyakan para pakar Ușül Fiqh secara konsensus bahwa bolehnya mengamalkan lafal al-' $\bar{A} m$ sebelum mencari mukhașșiș-nya (Al-Khuḍarī Bik, 1969).

Dapat dipahami dari penjelasan diatas bahwa kebanyakan pakar Ușül Fiqh memandang ketidakbolehan mengamalkan lafal al-' $\bar{A} m$ sebelum mencari mukhașșiṣ-nya.

Disebutkan dalam kitab Ușūl Fiqh yaitu:

$$
\text { وأما الذين يقولون بأن العام في الأصل حجة ظنية. }
$$

Maksudnya: 


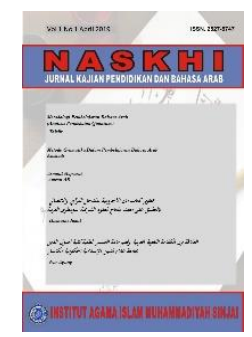

\section{NASKHI}

\section{Jurnal Kajian Pendidikan dan Bahasa Arab \\ Volume 3, No. 1, 2021}

ISSN (print) : 2527-5747

ISSN (online) : 2716-3369

Homepage : https://journal.iaimsinjai.ac.id/index.php/naskhi

Adapun pendapat yang mengatakan bahwa asal lafal al-'Am adalah hujjah zanniyah dan adapun pendapat yang mengatakan bahwa lafal al-'Amm adalah hujjah qaț'iyyah sebelum ditakhșiṣ (Al-Khuḍarī Bik, 1969).

Dapat dipahami dari penjelasan diatas bahwa, lafal al-'Amm sebelum di-takhșiș, ada yang mengatakan bahwa dia adalah hujjah zanniyah dan hujjah qat'izyah. Pendapat yang mengatakan hujjah zanniyah maka tentu lafal al-'Am tidak boleh langsung diamalkan atau tidak diperbolehkan pengamalannya, sebaliknya pada pendapat yang mengatakan bahwa lafal al-'Am adalah hujjah qat 'iyyah sebelum di-takhșiș, maka tentu diperbolehkan pengamalannya.

\section{Lafal Khās}

$K h \bar{a}$ ș menurut bahasa ialah memuat sesuatu baik lafal atau selainnya. Sedangkan secara istilah adalah lafal yang tidak dapat menerima dua arti ataupun lebih, sehingga makna yang dimaksud dari lafal khass ini, merupakan makna yang sudah tertentu yang diambil dari makna yang umum (Muslimin, 2012). Atau bisa dikatakan bahwa lafal $k h \bar{a} s$ adalah lafal yang tidak bisa memperoleh dua makna atau lebih dengan tanpa membatasi makna lafal khāṣ itu sendiri (Rosidin, 2020).

Muhammad al-Khuḍarī Bik memberikan definisi khās sebagai berikut.

$$
\text { والخاص ما ليس يعام }
$$

Maksudnya: 1969).

Khāṣ adalah suatu lafal yang menunjukkan suatu makna/arti secara mandiri (Al-Khuḍarī Bik,

Adapun menurut 'Abdul Wahhāb Khallāf definisi khāṣ sebagai berikut.

$$
\text { اللفظ الخاص :هُوَ لفظ وضع للدلالة على فرد واحد بالشخص }
$$

Maksudnya:

$K h \bar{a} s ̣$ ialah lafal yang digunakan untuk menunjukkan satu orang tertentu (Khallāf, t.th)

Lafal $k h \bar{a} s$ adalah lafal yang memuat satu pengertian secara tunggal atau beberapa pengertian yang terbatas. Para ulama ushul fiqh sepakat, bahwa lafal khās dalam nash syara', menunjuk kepada definisi yang khāṣ secara qaț'iy (pasti) dan hukum yang dikandungnya bersifat pasti selama tidak ada indikasi yang menunjukkan pengertian lain (Nurhayati dan Ali Imran Sinaga, 2019).

Lafal $k h \overline{a s s ~ i a l a h ~ l a f a l ~ y a n g ~ d i b u a t ~ u n t u k ~ m e m b e r i ~ d e f i n i s i ~ s a t u ~ s a t u a n ~ y a n g ~ t e r t e n t u . ~ B a i k ~}$ menunjuk pribadi seseorang, seperti lafal Muhammad, atau menunjuk macam sesuatu, seperti lafal insan (manusia) dan rajulun (orang laki-laki), atau menunjuk jenis sesuatu, seperti lafal hayawan (hewan), atau menunjuk benda konkrit atau abstrak, seperti lafal 'ilm (ilmu) dan jahl (kebodohan), atau penunjukkan arti kepada satu satuan itu secara hakiki atau i'tibari (anggapan) seperti lafal-lafal yang berfungsi untuk memberi peringatan banyak yang terbatas, seperti lafal tsalasah (tiga), mi'atun (seratus), jam'un (seluruhnya) dan fariq (kelompok) (Rosidin, 2020).

$K h \bar{a} s$ menurut bahasa ialah lawan daripada ' $\bar{A} m$. Sedangkan menurut istilah ialah suatu lafal yang menunjukkan arti tunggal yang menggunakan bentuk mufrad, baik definisi itu menunjuk pada jenis (إنسان), atau menunjuk macam (رجل), atau menunjuk arti perorangan (خالد), ataupun isim jumlah (ثلاثة) (Sahib, 2016)

Lafal khās itu menunjukkan kepada sesuatu yang tertentu seperti Musa, atau menunjukkan suatu macam/jenis seperti rajulun (seorang laki-laki), imra`atun (seorang wanita) atau bilangan tertentu seperti tiga, seratus, seribu. Lafal $k h \bar{a} s ̣$ itu dapat ditujukan kepada benda yang konkrit seperti contoh-contoh di atas, atau yang abstrak seperti ilmu, kecerdasan, kebodohan dan lain-lain (Pulungan, 2020). 


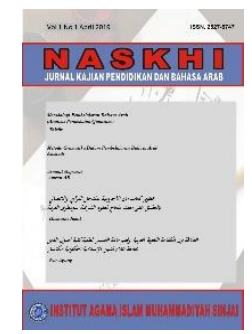

\section{NASKHI}

\section{Jurnal Kajian Pendidikan dan Bahasa Arab \\ Volume 3, No. 1, 2021}

ISSN (print) : 2527-5747

ISSN (online) : 2716-3369

Homepage : https://journal.iaimsinjai.ac.id/index.php/naskhi

Lafal $k h \bar{a} \bar{s}$ merupakan lawan dari lafal $\bar{A} m$, jika lafal $\bar{A} m$ memberikan arti umum, yaitu suatu lafal yang mencakup berbagai satuan-satuan yang banyak, maka lafal $k h \bar{a} s ̣$ adalah suatau lafal yang menunjukan makna khusus (Ikhwan, 20202).

Singkatnya bahwa setiap lafal yang menunjukkan arti tunggal itulah lafal khās dan menurut kesepakatan para ulama bahwa setiap lafal yang $k h \bar{a} s$, menunjukkan pengertian yang qat' 'iy yang tidak mengandung adanya kemungkinan-kemungkinan yang lain. Jika lafal itu berbentuk perintah maka memberi definisi mewajibkan yang diperintahkan itu, selama tidak terdapat dalil yang memalingkan perintah itu dari kewajiban (Sahib, 2016) . Pembahasan paling penting pada lafal $k h \bar{a} s \underline{\text { selain }}$ pada uraian mengenai makna dan macamnya, yaitu kehujjahan lafal tersebut. Mengenai hal ini, perlu dipahami terlebih dahulu bahwa para ulama sepakat bahwa dilālah-nya lafal khās adalah qaț'iy (Harisudin, 2020). Namun mereka berbeda pendapat dalam sifat ke-qat'iy-an itu, apakah lafal khāṣ yang yang dipandang qaț'iy dilālah-nya itu sudah jelas dengan sendirinya, sehingga tidak mempunyai kemungkinan penjelasan lain atau perubahan makna, ataukah sekalipun lafal khāṣ itu qat'izy dilālahnya, tetapi kemungkinan mempunyai perubahan dan penjelasan yang lain (Misbahuddin, 2015). Para ulama sepakat bahwa penunjukan (dilālah) lafal khās pada maknanya adalah bersifat qaț'iy (tegas dan pasti) selama tidak ada dalil lain yang dapat memalingkan dari makna hakikatnya (Harisudin, 2020).

Disebutkan dalam kitab Ușūl Fiqh yaitu:

$$
\text { وإذا ورد في النص لفظ خاص ثبت الحكم لمدلوله قطعا, ما لم يقم دليل على تأويله وإرادة معنى آخر منه }
$$

Maksudnya:

Apabila lafal khāṣ disebutkan pada nas maka hukum menjadi pasti terhadap apa yang disebutkan oleh dalil/nas itu secara qat'iy. Selama belum ada dalil yang mentakwilkannya dan maksud lain darinya (Khallaf, t.th).

Berdasarkan penjelasan atau uraian diatas, maka dapat dipahami bahwa lafal khāṣ adalah hujjah, karena para ulama sepakat bahwa dilālah-nya lafal khāṣ adalah qaț’i.

\section{Lafal Amr}

Menurut bahasa, kata al-Amr merupakan bentuk Mashdar dari kata أَمَر- يَأْهُرْ -أَمْرًا yang bermakna perintah, bentuk jamaknya adalah أَوَامرُ (Munawwir, 1997)

Al-Amr ialah suatu lafal yang dipergunakan oleh orang yang lebih tinggi kedudukannya untuk menuntut kepada orang yang lebih rendah derajatnya agar melakukan suatu perbuatan (Rosidin, 2020)

Amr adalah suatu tuntutan dari atasan kepada bawahan untuk mengerjakan suatu pekerjaan (Salih, 1984).

Menurut mayoritas ulama ushul fiqh, amar adalah suatu tuntutan (perintah) untuk melakukan sesuatu dari pihak yang kedudukannya lebih tinggi kepada pihak yang tingkatannya lebih rendah (Nurhayati dan Ali Imran Sinaga, 2019).

Menurut Wahbah az-Zuhaili dalam bukunya sebagai berikut.

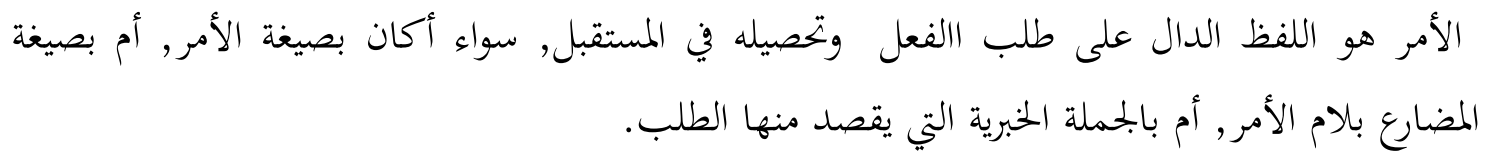

Maksudnya:

Al-Amr ialah lafal yang menunjukkan atas tuntutan perbuatan dan berlangsung pada waktu yang akan datang, sama adanya menggunakan șighat amr, ataukah dengan șighat fill mudhari yang diiringi lam amr, ataukah dengan jumlah khabariyyah yang ditujukan kepada maksud tuntutan (Zuhaili, 1999). 


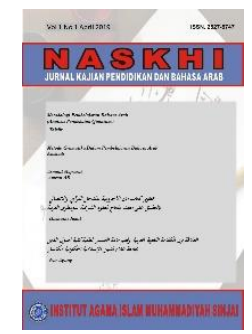

\section{NASKHI}

\section{Jurnal Kajian Pendidikan dan Bahasa Arab}

Volume 3, No. 1, 2021

ISSN (print) : 2527-5747

ISSN (online) : 2716-3369

Homepage : https://journal.iaimsinjai.ac.id/index.php/naskhi

Pembahasan paling penting pada lafal al-Amr selain pada uraian mengenai makna dan macamnya, yaitu kehujjahan lafal tersebut. Mengenai hal ini, perlu dipahami terlebih dahulu bahwa lafal al-Amr merupakan bagian dari lafal khāṣ, menurut jumhur ulama (Harisudin, 2020)

Disebutkan dalam kitab Ușūl Fiqh yaitu:

$$
\begin{aligned}
& \text { وإذا ورد في النص لفظ خاص ثبت الحكم لمدلوله قطعا, ما لم يقم دليل على تأويله وإرادة معنى آخر منه, } \\
& \text { فإن ورد مطلقا أفاد ثبوت الحكم على الإطلاق ما لم يوجد دليل تقييده, وإن ورد على على صيغة الأمر } \\
& \text { أفاد إيجاب المأمور به ما لم يوجد دليل يصرفه عن الإيجاب, وإن ورد على صيغة النهيي أفاد تحريم المنهي } \\
& \text { عنه ما لم يوجد دليل يصرفه عن التحريم (Khallaf,t.th). }
\end{aligned}
$$

Maksudnya:

Apabila lafal $k h \bar{a} s$ disebutkan pada nas maka hukum menjadi pasti terhadap apa yang disebutkan oleh dalil/nas itu secara qat'iy. Selama belum ada dalil yang mentakwilkannya dan maksud lain darinya. Maka apabila (lafal $k h \bar{a} s$ ) disebutkan secara mutlak maka itu berimplikasi kepastian hukum yang mutlak selama tidak ada dalil yang membatasi. Adapun jika (lafal khāṣ) disebutkan dalam bentuk perintah maka itu berimplikasi akan wajibnya sesuatu yang diperintahkan itu, selama belum ada dalil yang mengubahnya. Kemudian adapun jika (lafal

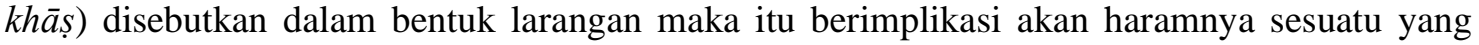
dilarang itu, selama belum ada dalil yang mengubahnya.

Disebutkan dalam kitab Ușül Fiqh yaitu:

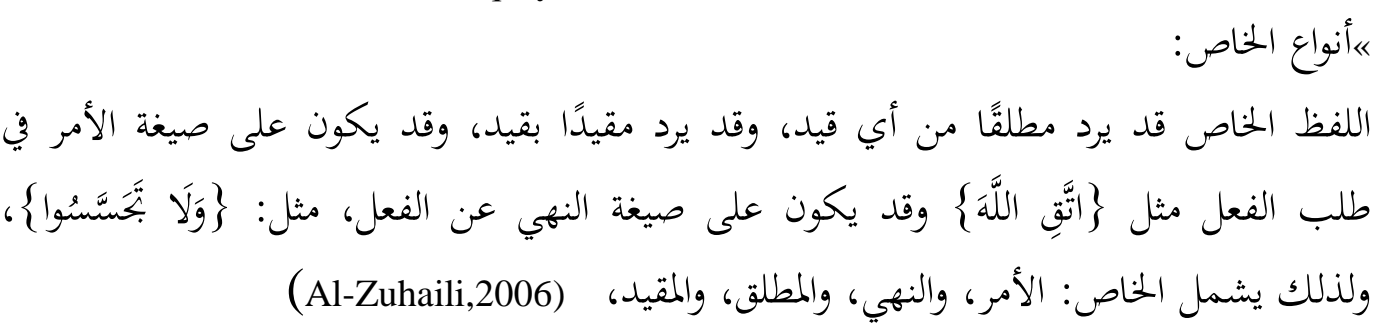

Maksudnya:

Macam-macam lafal khās:

Lafal khạs kadang-kadang disebutkan dalam bentuk mutlak dari apa saja yang mengikatnya dan terkadang disebutkan dalam bentuk muqayyad dengan sesuatu yang mengikatnya. Kemudian terkadang juga dalam bentuk perintah untuk permintaan mengerjakan sesuatu. Misalnya (bertaqwalah/takutlah kepada Allah). Terkadang juga dalam bentuk larangan untuk mengerjakan sesuatu, misalnya (dan janganlah kalian mencari-cari kesalahan), olehnya itu pada nas maka hukum menjadi pasti terhadap apa yang disebutkan oleh Lafal $k h \bar{a} s \underline{\text { mencakup: }}$ Perintah, larangan, mutlak, dan muqayyad.

Maka berdasarkan uraian di atas dapat dipahami bahwa lafal Amr adalah bagian dari lafal khāṣ, kemudian dari sinilah dapat dipahami juga bahwa lafal Amr dapat dijadikan sebagai hujah, karena dilālah-nya lafal khās adalah qat' 'iy.

4. Lafal Nahī disebutkan.

Menurut bahasa, kata Al-Nahyu bermakna larangan. Sebagaimana dalam Lisān al-Arab

$$
\text { النهي : خلاف الأمر(Manzūr, t.th) ). }
$$

Maksudnya: 


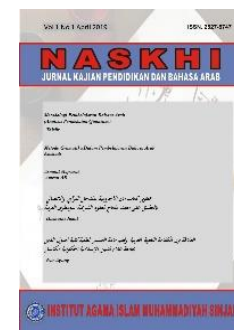

\section{NASKHI}

\section{Jurnal Kajian Pendidikan dan Bahasa Arab}

Volume 3, No. 1, 2021

ISSN (print) : 2527-5747

ISSN (online) : 2716-3369

Homepage : https://journal.iaimsinjai.ac.id/index.php/naskhi

Al-Nahyu: lawan/kebalikan dari al-amr/perintah.

Adapun dalam Mu'jam al-Wasīt disebutkan.

النهي : طلب الامتناع عن الشيء (Madkūr, 2004).

Maksudnya:

Al-Nahyu: Perintah atau permohonan dalam bentuk penolakan terhadap suatu hal.

Al-Nahyu ialah suatu lafal yang digunakan untuk menuntut agar meninggalkan suatu perbuatan (Rosidin, 2020) .

Diantara definisi nahiy adalah sebagai berikut.

$$
\text { هو طلب الترك من الأعلى إلى الأدنى (Misbahuddin, 2015). }
$$

Maksudnya:

Tuntutan untuk meninggalkan dari pihak yang lebih tinggi (kedudukannya) kepada yang lebih rendah.

Secara ringkas, al-nahiy adalah larangan melakukan suatu perbuatan, yang muncul dari pihak yang lebih tinggi kepada pihak yang lebih rendah. Nahiy merupakan perintah untuk meninggalkan suatu perbuatan atau perintah untuk tidak berbuat apa-apa (Nurhayati dan Ali Imran Sinaga, 2019).

Pembahasan paling penting pada lafal al-nahiy selain pada uraian mengenai makna dan macamnya, yaitu kehujjahan lafal tersebut. Mengenai hal ini, perlu dipahami terlebih dahulu bahwa lafal al-nahiy merupakan bagian dari lafal khās, menurut jumhur ulama (Rosidin, 2020).

Disebutkan dalam kitab Ușūl Fiqh yaitu:

$$
\begin{aligned}
& \text { وإذا ورد في النص لفظ خحاص ثبت الحكم لمدلوله قطعا, ما لم يقم دليل على تأويله وإرادة معنى آخر منه, } \\
& \text { فإن ورد مطلقا أفاد ثبوت الحلكم على الإطلاق ما لم يوجد دليل تقييده, وإن ورد على على صيغة الأمر } \\
& \text { أفاد إيجاب المأمور به ما لم يوجد دليل يصرفه عن الإيجاب, وإن ورد على صيغة النهيي أفاد تحريم المنهي } \\
& \text { عنه ما لم يوجد دليل يصرفه عن التحريم (Khallaf, t.th) }
\end{aligned}
$$

Maksudnya:

Apabila lafal khāṣ disebutkan pada nas maka hukum menjadi pasti terhadap apa yang disebutkan oleh dalil/nas itu secara qat'iy. Selama belum ada dalil yang mentakwilkannya dan maksud lain darinya. Maka apabila (lafal $k h \bar{a} s$ ) disebutkan secara mutlak maka itu berimplikasi kepastian hukum yang mutlak selama tidak ada dalil yang membatasi. Adapun jika (lafal khāss) disebutkan dalam bentuk perintah maka itu berimplikasi akan wajibnya sesuatu yang diperintahkan itu, selama belum ada dalil yang mengubahnya. Kemudian adapun jika (lafal $k h \bar{a} s$ ) disebutkan dalam bentuk larangan maka itu berimplikasi akan haramnya sesuatu yang dilarang itu, selama belum ada dalil yang mengubahnya.

Disebutkan dalam kitab Ușūl Fiqh yaitu:<smiles>CC[Al][14CH2][14CH3]</smiles>

اللفظ الخاص قد يرد مطلقًا من أي قيد، وقد يرد مقيدًا بقيد، وقد يكون على صيغة الأمر في طلب الفعل

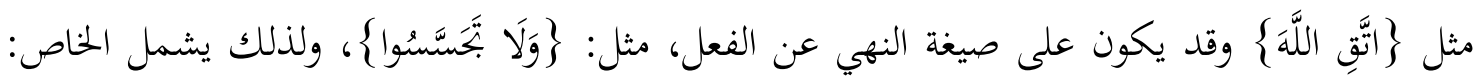
الأمر، والنهي، والمطلق، والمقيد، (Zuhaili,1999) 


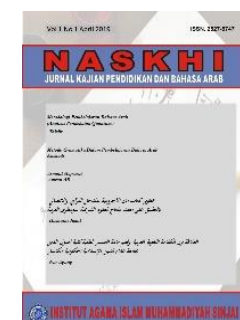

\section{NASKHI}

\section{Jurnal Kajian Pendidikan dan Bahasa Arab \\ Volume 3, No. 1, 2021}

ISSN (print) : 2527-5747

ISSN (online) : 2716-3369

Homepage : https://journal.iaimsinjai.ac.id/index.php/naskhi

\section{Maksudnya:}

Macam-macam lafal khās:

Lafal khāṣ kadang-kadang disebutkan dalam bentuk mutlak dari apa saja yang mengikatnya dan terkadang disebutkan dalam bentuk muqayyad dengan sesuatu yang mengikatnya. Kemudian terkadang juga dalam bentuk perintah untuk permintaan mengerjakan sesuatu. Misalnya (bertaqwalah/takutlah kepada Allah). Terkadang juga dalam bentuk larangan untuk mengerjakan sesuatu, misalnya (dan janganlah kalian mencari-cari kesalahan), olehnya itu pada nas maka hukum menjadi pasti terhadap apa yang disebutkan oleh Lafal khạs mencakup: Perintah, larangan, mutlak, dan muqayyad.

Maka berdasarkan uraian di atas dapat dipahami bahwa lafal al-nahiy adalah bagian dari lafal $k h \bar{a}$, kemudian dari sinilah dapat dipahami juga bahwa lafal al-nahiy dapat dijadikan sebagai hujah, karena dilālah-nya lafal $k h \bar{a} s \underline{\text { adalah }} q a t^{\prime} ’ i y$.

\section{B. Implementasi Lafal 'Ām, Khāṣ, Amr, dan Nahiy}

1. Lafal ' $\bar{A} m$

1) Lafal 'Ām yurādu bihi al-'Am. Yaitu 'Umūm yang tidak disertai qarinah yang menghapus kemungkinan untuk dikhususkannya. Sebagaimana dalam QS ‘'̄li ‘'Imrān/3:185.

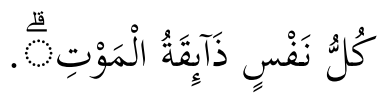

Terjemahnya:

Setiap yang bernyawa akan merasakan mati (Kemeng RI, 2002).

Kata كُلهُ نَفْسِ dalam ayat di atas, adalah șigat $\bar{A} m$ yang dari segi artinya dapat diketahui memang keumunannya tdiak dapat dibatasi, karena tidak satu pun dari semua makhluk hidup yang tidak akan merasakan kematian. Qarīnah yang menyertai di sini adalah qarinah haliyah atau merasakan keyakinan bersama. Lafal $\overline{A m}$ dalam bentuk ini penunjukannya terhadap umum adalah qat'iy (Syarifuddin, 2014).

2) 'Ām yurādu bihi al-khușuș. Yaitu 'Ám yang disertai qarinah yang menghilangkan arti umumnya dan menjelaskan bahwa yang dimaksud dengan ' $\bar{A} m$ itu adalah sebagian dari satunya.

Sebagaimana dalam QS ‘Āli ‘Imrān/3:97.

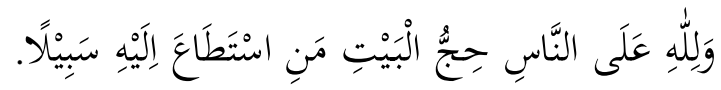

Terjemahnya:

Dan (di antara) kewajiban manusia terhadap Allah adalah melaksanakan ibadah haji ke Baitullah, yaitu bagi orang-orang yang mampu mengadakan perjalanan ke sana (Kemeng RI, 2002).

Lafal النَّاسِ dalam ayat ini adalah 'Ám karena ia kata tunggal yang diawali alif-lam Jinsiyyah. Walaupun lafalnya ' $\bar{A} m$ namun yang dikehendaki dalam ayat ini adalah sebagian afradnya saja (Syarifuddin, 2014).

3) ' $\bar{A} m$ Makhșuss, yaitu ' $\bar{A} m$ mutlak. Am yang tidak disertai qarinah yang menghilangkan kemungkinan dikhususkan dan menghilangkan keumumannya. Pada kebanyakan nash-nash yang didatangkan dengan shigat umum tidak disertai qarinah, sekalipun qarinah lafzhiyah (tertulis), 'aqliyah (dalam pemikiran) atau 'urfiyah (adat kebiasaan) yang menyatakan keumumannya atau kekhususannya. Lafal-lafal 'am semacam ini adalah jelas menunjukkan keumumannya selama tidak ada dalil yang mengkhususkannya (Rosidin, 2020). 


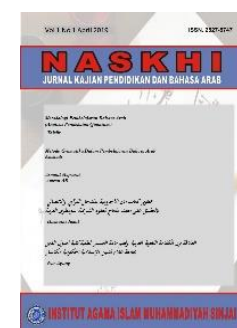

NASKHI

Jurnal Kajian Pendidikan dan Bahasa Arab

Volume 3, No. 1, 2021

ISSN (print) : 2527-5747

ISSN (online) : 2716-3369

Homepage : https://journal.iaimsinjai.ac.id/index.php/naskhi

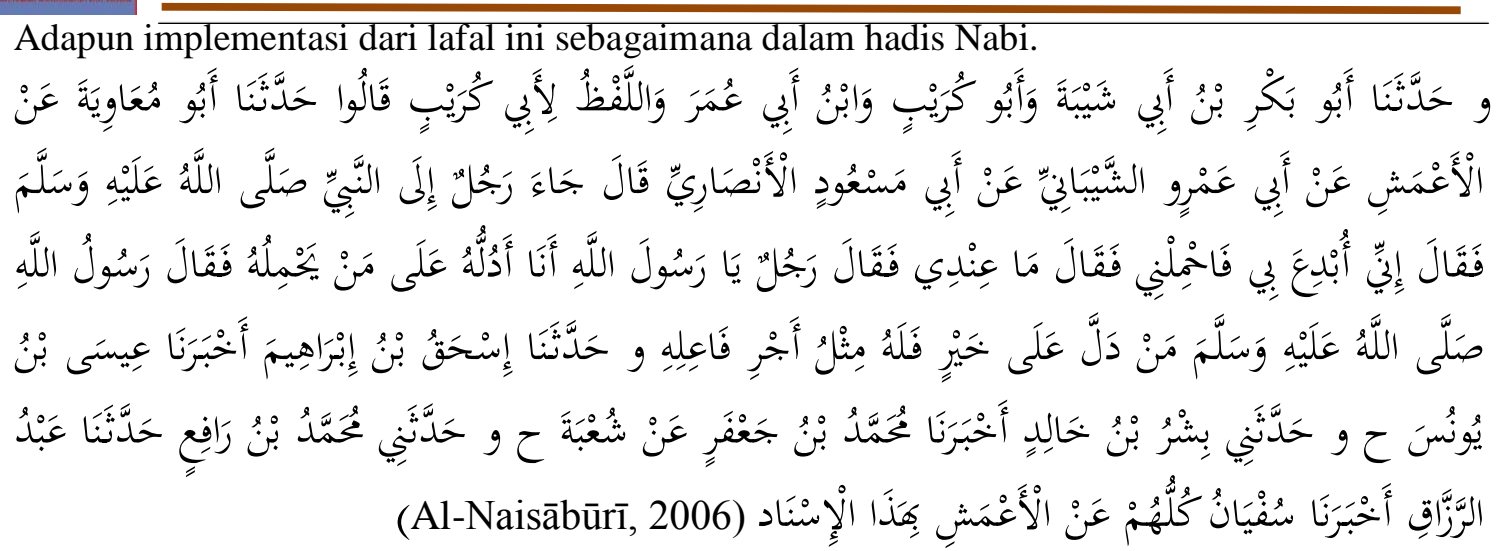

Artinya:

Telah menceritakan kepada kami [Abu Bakar bin Abu Syaibah] dan [Abu Kuraib] dan [Ibnu Abu Umar] dan ini adalah lafadz Abu Kuraib, mereka berkata; telah menceritakan kepada kami [Abu Mu'awiyah] dari [Al A'masy] dari [Abu 'Amru As Syaibani] dari [Abu Mas'ud Al Anshari] dia berkata, "Seorang laki-laki datang kepada Nabi shallallahu 'alaihi wasallam seraya berkata, "Wahai Rasulullah, jalan kami telah terputus karena hewan tungganganku telah mati, oleh karena itu bawalah saya dengan hewan tunggangan yang lain." Maka beliau bersabda: "Saya tidak memiliki (hewan tunggangan yang lain)." Tiba-tiba ada seorang laki-laki yang berkata, "Wahai Rasulullah, saya dapat menunjukkan seseorang yang dapat membawanya (memperoleh penggantinya)." Maka beliau bersabda: "Barangsiapa dapat menunjukkan suatu kebaikan, maka dia akan mendapatkan pahala seperti orang yang melakukannya." Dan telah menceritakan kepada kami [Ishaq bin Ibrahim] telah mengabarkan kepada kami [Isa bin Yunus]. (dalam jalur lain disebutkan) Telah menceritakan kepadaku [Bisyr bin Khalid] telah mengabarkan kepada kami [Muhammad bin Ja'far] dari [Syu'bah]. (dalam jalur lain disebutkan) Telah menceritakan kepadaku [Muhammad bin Rafi'] telah menceritakan kepada kami [Abdurrazaq] telah mengabarkan kepada kami [Sufyan] semuanya dari [Al A'masy] dengan sanad ini .

Lafal مَن dalam hadis tersebut berarti ' $\bar{A} m$, karena ia adalah isim mauṣul. Dalam lafal ini tidak terdapat tanda (qarīnah) apakah bermakna 'Ām atau Khușūṣ (Syarifuddin, 2014)

2. Lafal Khās

Diantara contoh lafal Khāṣ sebagaimana dalam QS an-Nur/24: 2

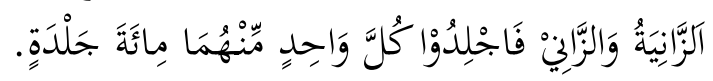

Terjemahnya:

Pezina perempuan dan pezina laki-laki, deralah masing-masing dari keduanya seratus kali (Kemeng RI, 2002).

Lafal 100 kali adalah khas karena menunjukkan 100 kali dera tidak boleh lebih atau kurang.

\section{Lafal Amr}

Bentuk amar kadang-kadang meninggalkan makna yang asli dan dipakai untuk makna yang bermacam-macam yang dapat diketahui dari susunan perkataan, antara lain:

a. Ijā $b$ (wajib)

Sebagaimana dalam QS an-Nisa/4: 77.

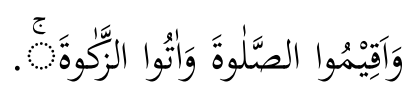




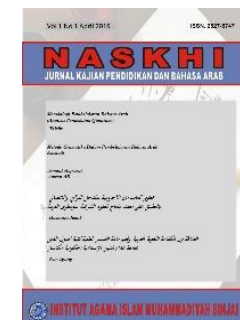

\section{NASKHI}

\section{Jurnal Kajian Pendidikan dan Bahasa Arab}

Volume 3, No. 1, 2021

ISSN (print) : 2527-5747

ISSN (online) : 2716-3369

Homepage : https://journal.iaimsinjai.ac.id/index.php/naskhi

Terjemahnya:

Laksanakanlah salat dan tunaikanlah zakat! (Kemeng RI, 2002)

Amar di dalam ayat ini berimplikasi hukum wajib meskipun tanpa qarīnah yang mengarahkannya untuk itu (Syarifuddin, 2014)

b. $N a d b$ (anjuran)

Sebagaimana dalam QS an-Nur/24: 33.

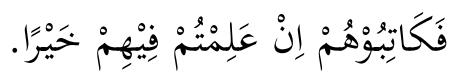

Terjemahnya:

Hendaklah kamu buat perjanjian kepada mereka, jika kamu mengetahui ada kebaikan pada mereka (Kemeng RI, 2002)

Lafal Katābah (الكتابة), yaitu kemerdekaan dengan pembayaran cicilan yang disuruh dalam ayat tersebut, berimplikasi hukum nadb, sehingga bagi yang beranggapan tidak perlu, maka tidak ada ancamannya apa-apa (Syarifuddin, 2014)

c. $T a{ }^{\prime} d \bar{i} b(\mathrm{adab})$

Sebagaimana dalam hadis nabi.

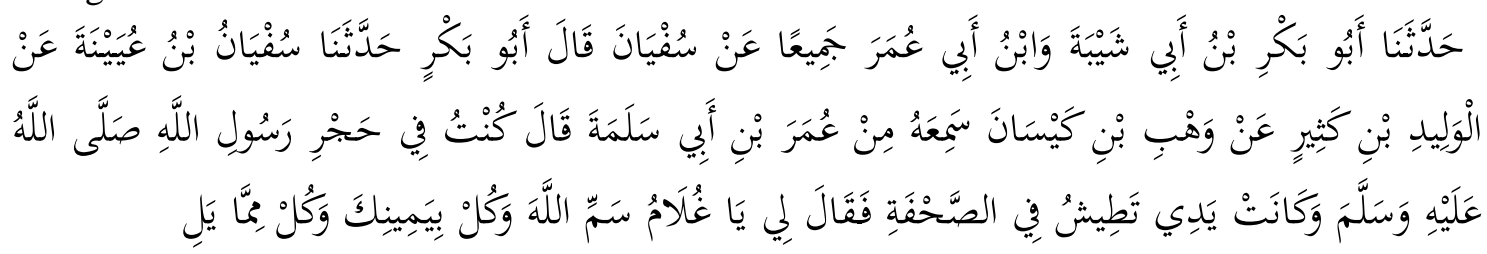

(Al-Naisābūrī, 2006)

Artinya:

Telah menceritakan kepada kami [Abu Bakr bin Abu Syaibah] dan [Ibnu Abu 'Umar] semuanya- dari [Sufyan]; Abu Bakr berkata; Telah menceritakan kepada kami [Sufyan bin 'Uyainah] dari [Al Walid bin Katsir] dari [Wahb bin Kaisan] yang dia dengar dari ['Umar bin Abu Salamah] ia berkata; Dulu aku berada di pangkuan Rasulullah shallallahu 'alaihi wasallam, lantas tanganku memegang piring, maka beliau bersabda kepadaku: "Wahai anak, sebutlah nama Allah, dan makanlah dengan tangan kananmu, serta makanlah yang ada di hadapanmu.

d. Irsyād ( menunjuki)

Sebagaimana dalam QS al-Baqarah/2: 282.

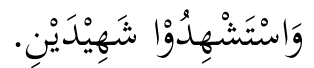

Terjemahnya:

Dan persaksikanlah dengan dua orang saksi (Kemeng RI, 2002)

Dalam ayat ini Allah SWT mendidik umat untuk menghadirkan dua saksi pada saat berlangsung transaksi utang piutang demi kemaslahatan mereka (Syarifuddin, 2014).

e. Ibāḥah (membolehkan)

Sebagaimana dalam QS al-Baqarah/2: 60.

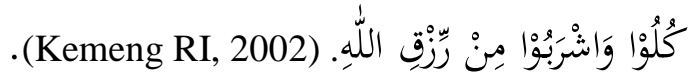

Terjemahnya:

Makan dan minumlah dari rezeki (yang diberikan) Allah. 


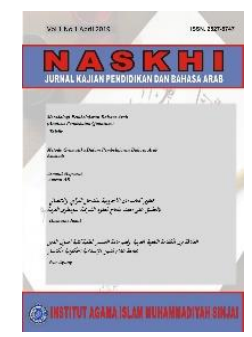

\section{NASKHI}

\section{Jurnal Kajian Pendidikan dan Bahasa Arab}

Volume 3, No. 1, 2021

ISSN (print) : 2527-5747

ISSN (online) : 2716-3369

Homepage : https://journal.iaimsinjai.ac.id/index.php/naskhi

Perintah dalam ayat ini tidak memuat tuntutan apa-apa terhadap orang yang menerima amar sehingga tidak ada sanksi berupa hukuman maupun janji pahala.

\section{f. Tahdìd (ancaman)}

Sebagaimana dalam QS Ibrahim/14: 30.

$$
\text { قُلْ تَتَنَّعُوْا فَاِنَّ مَصِيْرَكُمْ الِلَى النَّارِ. }
$$

Terjemahnya:

Katakanlah (Muhammad), "Bersenang-senanglah kamu, karena sesungguhnya tempat kembalimu ke neraka. (Kemeng RI, 2002)

Walaupun dalam ayat ini digunakan kata amar, namun tidak memuat tuntutan apa-apa. Bedanya dengan Ibāhah di atas, adalah dalam wujud Tahdīd ini disebutkan janji yang tidak enak (Syarifuddin, 2014)

g. Ikrām (memuliakan)

Sebagaimana dalam QS al-Hijr/15: 46.

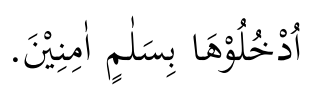

Terjemahnya:

Masuklah ke dalamnya dengan sejahtera dan aman (Kemeng RI, 2002)

Amar dalam ayat ini tidak memuat tuntutan apa-apa terhadap yang menerima amar tersebut.

\section{h. Taskhīr (penghinaan)}

Sebagaimana dalam QS al-Baqarah/2: 65.

$$
\text { كُوْنُوْا قِرَدَةً خَاسِيْنِنَ. }
$$

Terjemahnya:

Jadilah kamu kera yang hina! (Syarifuddin, 2014)

Walaupun dalam ayat ini terdapat penggunaan kata amar, namun tidak memuat arti tuntutan; tidak mungkin Allah menuntut orang menjadi Kera

j. Ta'jiz (melelahkan)

Sebagaimana dalam QS al-Baqarah/2: 23.

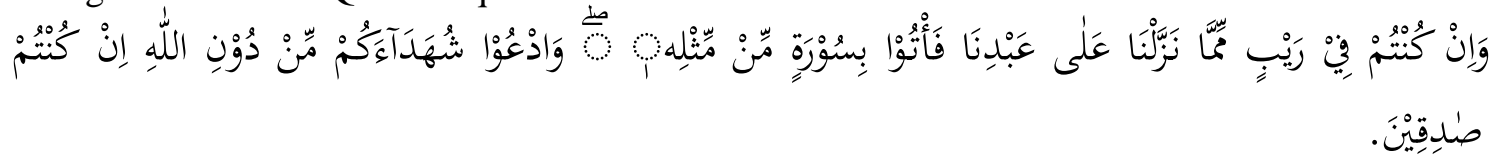

Terjemahnya:

Dan jika kamu meragukan (Al-Qur'an) yang Kami turunkan kepada hamba Kami (Muhammad), maka buatlah satu surah semisal dengannya dan ajaklah penolong-penolongmu selain Allah, jika kamu orang-orang yang benar (Kemeng RI, 2002).

Allah sebenarnya mengetahui bahwa orang diperintah dalam ayat ini tidak akan mungkin mampu membuat satu ayat pun yang semisal dengan ayat al-Qur'an. Namun Allah menyuruhnya juga untuk melakukan demikian. Perintah ini bukan dalam arti yang sebenarnya, tetapi hanya sekedar menyatakan ketidakmampuan manusia (Syarifuddin, 2014)

k. Taswiyah (menyamakan)

Sebagaimana dalam QS at- Țūr/52: 16.

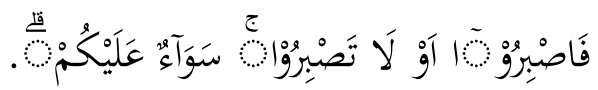




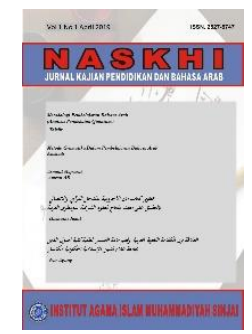

NASKHI

Jurnal Kajian Pendidikan dan Bahasa Arab

Volume 3, No. 1, 2021

ISSN (print) : 2527-5747

ISSN (online) : 2716-3369

Homepage : https://journal.iaimsinjai.ac.id/index.php/naskhi

Terjemahnya:

Baik kamu bersabar atau tidak, sama saja bagimu (Kemeng RI, 2002).

Amar dalam ayat ini tentu bukan memerintahkan mereka untuk sabar tetapi menyatakan bahwa apakah mereka akan bersabar atau tidak, adalah sama saja bagi mereka (Syarifuddin, 2014).

1. $D u$ 'à (berdo'a)

Sebagaimana dalam QS Ibrahim/14: 41.

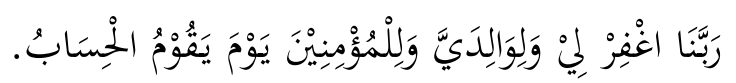

Terjemahnya:

Ya Tuhan kami, ampunilah aku dan kedua ibu bapakku dan semua orang yang beriman pada hari diadakan perhitungan (hari Kiamat) (Kemeng RI, 2002).

Amar yang dilafalkan oleh seseorang hamba kepada Tuhannya tentu tidak dapat dikatakan sebagai amara dalam makna sebenarnya. Oleh karena itu, amar disini berarti permohonan (do'a) (Syarifuddin, 2014)

m. Ihānah (meremehkan)

Sebagaimana dalam QS ad-Dukhan/44: 49.

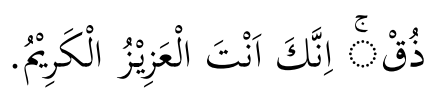

Terjemahnya: 2002).

Rasakanlah, sesungguhnya kamu benar-benar orang yang perkasa lagi mulia (Kemeng RI,

Pada ayat ini Allah berkata kepada orang kafir yang dimasukkan ke dalam neraka. Tentu maksudnya bukan memerintahkan untuk melakukan seperti apa yang dikatakan, tetapi hanya sekedar menghinakan orang kafir (Syarifuddin, 2014)

n. Imtinān.

Sebagaimana dalam QS al-An'am/6: 142.

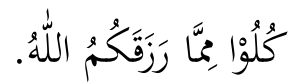

Terjemahnya:

Makanlah rezeki yang diberikan Allah kepadamu (Kemeng RI, 2002).

Pada Imtinān ada qarīnah berupa kebutuhan kita kepadanya dan kemustahilan kita untuk melakukannya (Syarifuddin, 2014)

4. Lafal Nahī

Bentuk nahi kadang-kadang digunakan untuk beberapa arti (makna) yang asli yang dapat diketahui dari susunan perkataan, antara lain:

a. Haram

Sebagaimana dalam QS al-Isra/17: 33.

Terjemahnya: 2002).

Dan janganlah kamu membunuh orang yang diharamkan Allah (membunuhnya) (Kemeng RI,

b. Makruh

Sebagaimana dalam hadis nabi. 


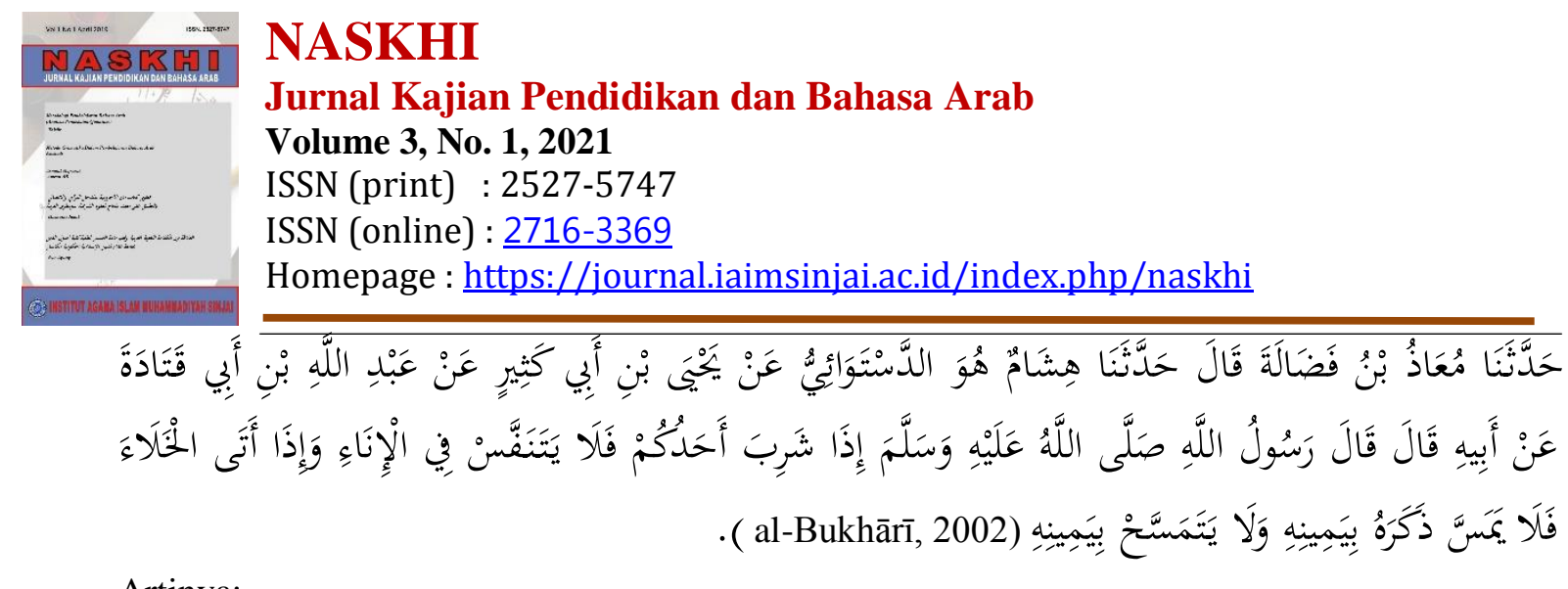

Artinya:

Telah menceritakan kepada kami [Mu'adz bin Fadlalah] berkata, telah menceritakan kepada kami [Hisyam] -yaitu Al Dastawa'I- dari [Yahya bin Abu Katsir] dari ['Abdullah bin Abu Qatadah] dari [Bapaknya] ia berkata, "Rasulullah shallallahu 'alaihi wasallam telah bersabda: "Jika salah seorang dari kalian minum, maka janganlah ia bernafas dalam gelas. Dan jika masuk ke dalam WC janganlah dia menyentuh kemaluannya dengan tangan kanannya dan jangan membersihkan dengan tangan kanannya.

c. $D u^{\prime} \bar{a}$ (berdo'a)

Sebagaimana dalam QS Āli 'Imrān /3: 8 .

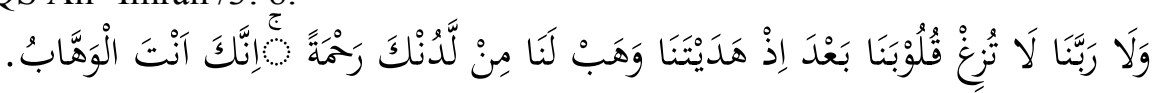

Terjemahnya:

(Mereka berdoa), "Ya Tuhan kami, janganlah Engkau condongkan hati kami kepada kesesatan setelah Engkau berikan petunjuk kepada kami, dan karuniakanlah kepada kami rahmat dari sisi$\mathrm{Mu}$, sesungguhnya Engkau Maha Pemberi (Kemeng RI, 2002).

d. Irsyād (menunjuki)

Sebagaimana dalam QS al-Maidah/5: 101.

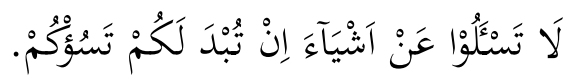

Terjemahnya:

Janganlah kamu menanyakan (kepada Nabimu) hal-hal yang jika diterangkan kepadamu (justru) menyusahkan kamu (Kemeng RI, 2002).

e. Tais (Memutus-asakan)

Sebagaimana dalam QS at-Tahrim /66: 7.

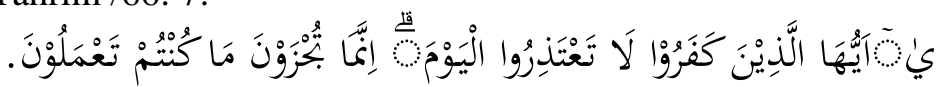

Terjemahnya:

Wahai orang-orang kafir! Janganlah kamu mengemukakan alasan pada hari ini. Sesungguhnya kamu hanya diberi balasan menurut apa yang telah kamu kerjakan (Kemeng RI, 2002).

\section{f. Tahqīr (Merendahkan)}

Sebagaimana dalam QS al-Hijr/15: 88.

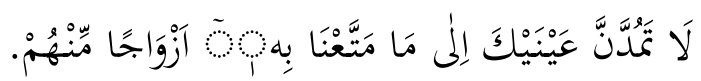

Terjemahnya:

Jangan sekali-kali engkau (Muhammad) tujukan pandanganmu kepada kenikmatan hidup yang telah Kami berikan kepada beberapa golongan di antara mereka (orang kafir) (Kemeng RI, 2002). 


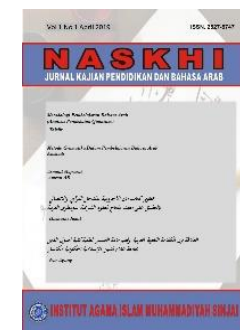

\section{NASKHI}

\section{Jurnal Kajian Pendidikan dan Bahasa Arab}

Volume 3, No. 1, 2021

ISSN (print) : 2527-5747

ISSN (online) : 2716-3369

Homepage : https://journal.iaimsinjai.ac.id/index.php/naskhi

g. Bayān al-'Äqibah (Penjelasan Akibat) (Amar dan Nahi I, 2020)

Sebagaimana dalam QS Ibrahim/14: 42.

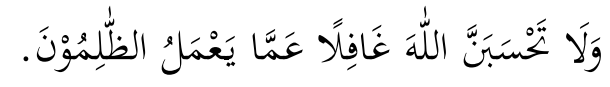

Terjemahnya:

Dan janganlah engkau mengira, bahwa Allah lengah dari apa yang diperbuat oleh orang yang zalim (Kemenag, 2002).

\section{Simpulan}

Berdasarkan penjelasan dalam pembahasan di atas, maka dapat ditarik kesimpulan dalam beberapa poin sebagai berikut:

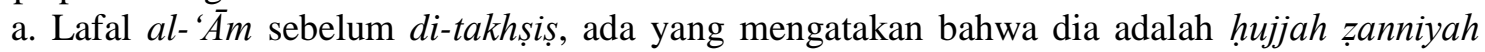
dan hujjah qaț'iyyah. Kemudian lafal khās adalah hujjah, karena para ulama sepakat bahwa dilālahnya lafal $k h \bar{a} s \underline{\text { adalah }} q a t^{\prime} i$. Adapun lafal Amr dan Nahiy adalah bagian dari lafal $k h \bar{a} s$, kemudian dari sinilah dapat dipahami juga bahwa lafal Amr dan Nahiy dapat dijadikan sebagai hujjah, karena dilālah-nya lafal khāṣ adalah qat'izy.

b. Implementasi Lafal ' $\bar{A} m$, Khās, Amr, dan Nahiy masing-masing tidak hanya mencakup pada asalnya, namun luas cakupannya.

\section{Daftar Pustaka}

Ali, Muhammad. (11 Oktober 2020). "Polemik Menag Terkait Radikalisme: Dari Cadar, Celana Cingkrang hingga Good Looking dan Hafiz", Liputan 6, 05 September 2020. https://www.liputan6.com/news/read/4348340/polemik-menag-terkait-radikalismedari-cadar-celana-cingkrang-hingga-good-looking-dan-hafiz.

Ali, Mohammad Daud. (2015). Hukum Islam; Pengantar Ilmu Hukum dan Tata Hukum Islam di Indonesia. Cet. 21; Jakarta: PT RajaGrafindo Persada.

Al-Naisābūrī, Muslim bin al-Hajjāj al-Qusyairī. (2006M/1427H) Sạhịḥ Muslim, Jilid II. Cet. 1; Riyāḍ: Dār Ṭaibah Li al-Nasyr wa al-Taūzī.

Al-Zuhailī, Muhammad Musțafā. (2006M/1427H). al-Waj̄̄z F̄̄ Ușūl al-Fiqh al-Islāmī, Juz 2. Cet. 8: Dimasyq.: Dār al-Khair Lī al-Tibā'ah Wa al-Nasyr.

Amar dan Nahi I. (24 Oktober 2020). academia.edu, https://www.academia.edu/8422221/AMAR_DAN_NAHI_I.

Bakry, Nazar. (2003). Fiqh \& Ushul Fiqh. Jakarta: PT Raja Grafindo Persada.

al-Bukhārī, Muḥammad bin Isma'îl. Șaḥịh al-Bukhārī. (2002M/1423H). Cet. 1; Dimasyq: Dār Ibnu Kasīir.

Harisudin, M. Noor. ( 2020). ILMU USHUL FIKIH I. Jember: Instrans Publishing.

Ikhwan, Mohammad Nor. (2002). Memahami Bahasa Al-Qur'an. Jogjakarta: Pustaka Pelajar. 


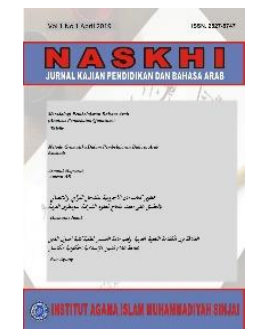

Jurnal Kajian Pendidikan dan Bahasa Arab

Volume 3, No. 1, 2021

ISSN (print) : 2527-5747

ISSN (online) : 2716-3369

Homepage : https://journal.iaimsinjai.ac.id/index.php/naskhi

Kementerian Agama Republik Indonesia. (2002M). Mushaf al-Qur'an dan Terjemah. Depok-Jakarta: al-Huda Kelompok Gema Insani.

Khallāf, ‘Abdul Wahhāb. (t.th.). 'Ilmu Ușul al-Fiqh. Cet. 8: t.t.p.: Dār al-Qālam.

al-Khuḍarī Bik, Muḥammad.( 1969M/1389H). Ușul al-Fiqh. Cet. 6: al-Maktabah alTijāriyyah al-Kubrā.

Misbahuddin. (2015). Ushul Fiqh II. Makassar: Alauddin Press.

Munawwir, Ahmad Warson.( 1997). Al-Munawwir Kamus Arab-Indonesia. Cet XIV: Surabaya: Pustaka Progressif.

Munawwir, Ahmad Warson. (1997). Al-Munawwir: Kamus Arab-Indonesia. Surabaya: Pustaka Progresif.

Muslimin. (2012)."Urgensi Memahami Lafal 'Ām dan Khāṣ Dalam al-Qur'an " Tribakti; Jurnal Pemikiran Keislaman. vol. 23 no. 2, h. 139, https://ejournal.iaitribakti.ac.id/index.php/tribakti/article/view/33.

Nurhayati dan Ali Imran Sinaga. (2019). Fiqh dan Ushul Fiqh. Cet. 2: Jakarta: Prenada Media Group.

Pulungan, Enny Nazrah. (22 Oktober 2020). Diktat Fikih Usul Fikih. http://repository.uinsu.ac.id/8531/1/Diktat.pdf.

Rosidin, Dedeng. Diktat Usul Fikih. (22 Oktober 2020). http://file.upi.edu/Direktori/FPBS/JUR._PEND._BAHASA_ARAB/19551007199001 1-DEDENG_ROSIDIN/DIKTAT_USHUL_FIQIH.pdf.

Sahib, Muhammad Amin. (2016). "Lafaz Ditinjau dari Segi Cakupannya ('Am - Khas Muthlaq - Muqayyad)." Diktum; Jurnal Syariah dan Hukum, vol. 14 no. 2, h. 139, https://ejurnal.iainpare.ac.id/index.php/diktum/article/view/229.

Salih, Muhammad Adib. (1984). Tafsir an-Nusus fi al-Figh al-Islami, jilid I. Beirut : alMaktab al-Islami.

Syafe'i, Rachmat. (2007). Ilmu Ushul Fiqih. Cet. III; Bandung: CV Pustaka Setiaji.

Syarifuddin, Amir. 2014. Ushul Fiqh Jilid 2 (Cet. 7). Jakarta: Kencana Prenada Media Group

Zahra, Muhammad Abu. (1999). Ushul Fiqh. Jakarta: Pustaka Firdaus.

Zuhaili, Wahbah. (1999). Al-Wajizfi Ushul Fiqh. Damaskus: Dār al Fikri. 